\title{
THE MEXICAN PETROLEUM COMPANY'S AMPARO CASE*
}

\author{
Carlos Berguido, Jr.
}

On November I7th last the Supreme Court of Mexico decided in favor of the company the amparo case of the Mexican Petroleum Company against acts of the Secretary of Industry, Commerce and Labor and of the Petroleum Agency in Tampico. Not since the now celebrated Texas Company amparo ${ }^{1}$ has a decision of the Supreme Court of Mexico attracted as much attention or been read with as great interest, both by lawyers and laymen on either side of the Rio Grande. In view of the importance of the present decision and of the widespread comment it has already aroused, it is our purpose to analyze the Court's decision and to endeavor to point out its meaning and possible effect.

We do not deem it necessary to explain fully what the remedy of amparo is under Mexican Constitutional Law and Practice, ${ }^{2}$ nor do we consider it desirable or feasible to discuss . the entire petroleum question, since the adoption of the famous Article 27 of the Mexican Constitution of I917.8 We shall, how-

*The Mexican writ of amparo is a Federal writ, "the purpose whereof is to make the supremacy of the Constitution effective over all other inferior laws, and which, entrusted to the Federal Courts, and particularly the Supreme Court, imposes on them the important duty of fixing and establishing the true meaning and application of the principles of Constitutional Law and of preventing the infringement of the said principles by any one of the branches of the Federal or State governments." Lic. Benito Flores, op. cit. infra note 2.

${ }^{1}$ In the Supreme Court of Mexico, Aug. 31, I92I. Discussed in a very lucid article by Edward Schuster, of the New York Bar, in (I92I) 7 A. B. A. JourN., 583-589, "The Texas Company's Amparo Case." See also U. S. Daily, March 23,1927 , at 214.

"For the text of the Amparo Law, see "LEY DE AMPARo" (Mexico I93I) with "Comentarios" by Lic. Eduardo Pallares. See also the excellent treatise by Lic. Emilio Rabasa, "EL JuIcio Constrrucional" (Mexico IgIg). For a brief discussion in English of the origin and operation of the remedy of amparo, see "The Writ of Amparo under Mexican Law" by a former Associate Justice of the Supreme Court of Mexico, Lic. Benito Flores, in (I92I) 7 A. B. A. JouRn. 388-392, and the introductory remarks by Edward Schuster, of the New York Bar, op. cit. at 583 .

"For a clear exposition of some of the legal aspects of the petroleum question from the American viewpoint, see "Mexican Oil Legislation and International Law," by Ira Jewell Williams, of the Philadelphia Bar, in (I927) I TEMPLE LAW QUARTERLY 9I-ro2. For a statement of the Mexican side, see "I A CuESTÍ́N DEZ PETróleo" (Mexico I92I), by Lic. Diaz Dufoo. 
ever, try to indicate how the case arose, what the contentions of the respective parties were, both in the District Court and in the Supreme Court, and what the Supreme Court decided.

The facts are comparatively simple. Complainant, the Mexican Petroleum Company, a California corporation, duly registered and authorized to do business in Mexico, acquired certain lands in the former Hacienda of Chapacao, State of Vera Cruz, prior to May I, I II $7^{4}$ and carried on there works of petroleum exploration and exploitation. On January II, I927, three drilling permits previously issued to the company were cancelled by the Petroleum Agency in Tampico under express orders of the Department of Industry, Commerce and Labor, solely on the ground that the company had failed to comply with the new Petroleum Law, by not applying for (so-called) "confirmatory concessions" within one year from the promulgation of the law." The Company petitioned the District Judge of Villa Cuauhtemoc, Vera Cruz, for amparo to restrain the Petroleum Agency in Tampico and the Secretary of Industry, Commerce and Labor from cancelling the drilling permits and enforcing the Petroleum Law. The Company averred, inter alia, the following violations of constitutional guaranties: (I) of Article 4 of the Constitution, ${ }^{6}$ because Article ${ }^{5} 5$ of the Law ${ }^{7}$ deprives the company of the product of its labor; (2) of Article I4 of the Constitution, ${ }^{8}$ because Article 27 of the Constitution is applied retroactively; (3) of Article I4 of the Constitution, ${ }^{9}$ because the cancellation of its drilling permits deprives the Company of its

The effective date of the new Mexican Constitution.

${ }^{\circ}$ Articles I4 and I5, Law of December 3I, 1925, Diario Oficial.

- ". . No one shall be deprived of the fruit of his labor, except by judicial decree." Art. 4, Constitution of IgI?.

I "The corfirmation of the rights to which Articles I2 and I4 of this law refer shall be solicited within a period of one year reckoned from the date of this law's taking effect; this period having elapsed said rights shall be considered as waived, and rights whose confirmation may not have been solicited shall have no effect whatever as against the Federai Government." Art. I5, Law of December 3I, 1025 .

"No law shali be given retroactive effeer to tine prejudice of any person whatsoever . . " A.rt. I4, Constitution of Ior?.

○ “. . . No person shall be deprived of life, liberty, property, possessions or rights with ut uue process of lav" nstituted before $a$ duly created court, in which the essertial elements of procedure are observed and in accordance with previously exis:ing laws . . ." Arl. I4, Constitution of 1917. 
property, possessions and rights, without due process of law, in that in so applying Article I5 of the Law the rights of the Company in the subsoil, which were acquired in accordance with previously existing laws, are ignored; (4) of Article I6 of the Constitution, ${ }^{10}$ because without legal cause, the Company is molested by the defendants in its possessions; (5) of Article 22 of the Constitution, ${ }^{11}$ because Article ${ }^{15}$ of the Law punishes with confiscation those who, like the company, have not consented to exchange their old titles for new, particularly since the complainant is a foreign company; (6) of Article 27 of the Constitution, ${ }^{12}$ in that retroactive effect is given to Articles $14^{13}$ and $15^{14}$ of the Law; (7) of Article 27 of the Constitution, ${ }^{15}$ since no one may be deprived of his property except by expropriation for reasons of public utility and by means of indemnification.

One of the defendants, the Secretary of Industry, Commerce and Labor, in his answer set up that the drilling permits were given merely provisionally and expressly subject to the Petroleum Law (when enacted); that the Company voluntarily waived its rights to the subsoil by failing to apply for confirm-

${ }^{10}$ "No one shall be molested in his person, family, domicile, papers or possessions, except by virtue of an order in writing of the competent authority setting forth the legal ground and justification for the action taken . . " Art. 16, Constitution of I9I7.

11 ". - . confiscation of property and any other penalties, unusual or working corruption of the blood, are prohibited." Art. 22, Constitution of I9I7.

In ". In the Nation is vested direct ownership of all minerals or substances which in veins, layers, masses, or beds constitute deposits whose nature is different from the components of the land, such as . Petroleum and all hydrocarbons-solid, liquid or gaseous . . " Par. $4 ;$ Art. 27 , Constitution of I9I7.

Is "Without any cost, and by means of concessions granted pursuant to this law, the following rights shall be confirmed:

I. Those that may be derived from lands on which operation of petroleum exploitation may have been commenced prior to May I, I9I7.

II. Those that may be derived from contracts executed by the surface owner or his assigns prior to May $x$, I917, for the express purpose of petroleum exploitation.

The confirmation of these rights cannot be granted for more than fifty years, reckoned from the time when exploitation work may have commenced in the case of Section I, and, in the case of Section II, from the date when the contracts are executed . . ." Art. I4, Law of December 3I, 1925.

"Supra note 7.

13 "Private property shall not be expropriated except for reasons of public utility and by means of indemnification." Par. 2, Art. 27, Constitution of ror7. 
atory concessions, and hence could not be aggrieved by the cancellation of the drilling permits, since it had failed to comply with the Law, upon which the permits depended for their validity; that in any event, before the Company could have any standing in court, it had to prove the existence of its rights. The other defendant, the Petroleum Agent in Tampico, did not answer.

At the hearing before the District Court, the Company offered in evidence certified copies of the deeds by which it claimed to have acquired its rights and oral proof of its works of exploration and exploitation prior to May I, I9I7. The District Court granted the amparo on the ground that the Company had been deprived of its rights of exploration and exploitation to the subsoil of Chapacao without due process of law, because under. Article 27 of the Constitution, the nationalization of petroleum must be made effective through the Courts, and not by administrative orders.

Both defendants, the representative of the Attorney General (who is always a necessary party. in amparo proceedings) and, curiously enough, the complainant also, appealed. The complainant was satisfied with the judgment, but apparently thought that the decision should have gone' further and been based on other grounds. On appeal, the representative of the Attorney General (Ministerio Publico) moved that the decision of the lower Court be reversed, on the ground that since the drilling permits were provisional only and subject to the provisions of the Petroleum Law, they could be cancelled if the Company failed to comply with the Law, and, since it had voluntarily failed to apply for confirmation of any rights which it may have had, the cancellation of the permits was lawful, without the necessity of a suit, because for the cancellation of adminis- trative permits no such formality is required. He also claimed that since the Company had failed to prove its rights, the judgment of the lower Court in its favor was in error. Similarly, defendants argued on appeal, first that the judgment was in contradiction of the reasoning on which it was based; secondly, that the right protected was a mere expectation, rather than a vested 
right; thirdly, that in accordance with Article I 5 of the Law, ${ }^{16}$ the Company's rights must be considered as waived for failure to apply for confirmation; and fourthly, that the lower Court had failed to consider the clause in the driliing permits making them provisional and subject to the Petroleum Law. The Company contended that the mere requirement of Article I4 of the Law ${ }^{17}$ that it apply for confirmation of its pre-constitutional rights, which can only be granted by means of a concession was in itself a violation of the constitutional guaranties. It reasserted the other grounds for relief that we have already discussed. ${ }^{18}$

The Supreme Court convened in plenary session on November I7, I927. At that time eleven justices ("Magistrados") were present: Chief Justice Díaz Lombardo, and Justices Guzmán Vaca, Olea, Urbina, Vicencio, Castro, Estrada, Padilla, Ramírez, Orantes and Cisneros Canto. Justice Ramírez had prepared the opinion of the Court. After the reading thereof Justice Urbina delivered a concurring opinion ${ }^{19}$ and Chief Justice Díaz Lombardo and Justice Cisneros Canto delivered opinions dissenting in part. A formal vote being taken, nine Justices voted in favor of the opinion as read. Chief Justice Díaz Lombardo and Justice Cisneros Canto dissented in part, but both concurred in granting: amparo. The Supreme Court, in affirming the decision of the District Court (without concurring in the reasoning thereof), issued the following order:

"The Justice of the Union shelters and protects the Mexican Petroleum Company of California against the acts of which it complains consisting in the revocation of the permits granted by the Secretary of Industry, Commerce and Labor, to drill wells, 'Mendez No. 27,' 'Chijol No. 63' and 'Dicha No. I04,' in the lands of the former Hacienda of

16 Supra note 7 .

${ }^{27}$ Supra note 13.

${ }^{13}$ Supra notes 6 to 15 .

${ }^{2}$ This opinion avowedly concerns itself, not with legalistic principles, but with the economic, social and political aspects of the petroleum question. It is perhaps indicative of the views of the Administration and was probably inspired. Sed quaere, would not this be true also of the majority opinion? 
Chapacao, Municipality of Panuco, State of Vera Cruz, basing such revocation on Articles I4 and I5 of the Petroleum Law, regulating Article 27 of the Federal Constitution, and applying the sanction established by the said Article I5."

The decision of the Court, in accordance with Mexican practice, is divided into three parts: The "Resulting" clauses ("Resultandos"), in which the Court reviews the facts as developed in the pleadings, as well as the legal arguments advanced by the respective parties in the Court below, then the "Considering" clauses ("Considerandos"), in which the legal basis of the Court's decision is set forth, and finally the Judgment itself ("Puntos Resolutivos"). ${ }^{20}$ In the consideranda the Court takes up the contending arguments: first of the defendants, then of the Attorney General, and finally of the complainant. But, as pointed out in the dissenting opinion by Justice Cisneros Canto, the Court does not even attempt to answer all the points presented by the parties. It finds that defendant's argument that the decision of the lower Court is contradictory is without merit, because even if there were contradiction-which is not conceded-the decision below rests on solid constitutional grounds, the violation of Articles $14,{ }^{21} 16^{22}$ and $27^{23}$ of the Constitution. The second point raised by defendants is also found without merit. Says the Court:

"It is not true that a mere expectation of rights is involved, because, in addition to the fact that the District Judge only referred to the rights of exploration and exploitation granted to the complainant, those rights exist, not in prospect, but by virtue of the works that the complainant has carried out with the respective permits and under the protection of general laws previously enacted, and, at least for that reason, a mere expectancy is not involved ..."

\footnotetext{
${ }^{20}$ The majority opinion quoted supra p. $29 \mathrm{I}$.

${ }^{21}$ Supra notes 8 and 9.

${ }^{22}$ Supra note 10.

${ }^{23}$ Supra note 12.
} 
The real meat of the whole case, its ratio decidendi, is found in the following language overruling defendant's third point: ${ }^{24}$

"Consequently, if the complainant company could not apply for the confirmation of its pre-existing rights, except with a limitation as to time in regard thereto, it is beyond doubt that it was indispensable that such a restriction should first disappear, and therefore, the term of one year established therefor by Article I5 could not run, in view of the impossibility to which reference has been made; and since the Secretary of Industry, Commerce and Labor, in violation of the principles previously expressed, cancelled the permits granted to the complainant company, relying on the lapse of the said term, without taking in consideration the unconstitutionality of the 50-year limitation, a necessary condition for confirmation, it is undisputable that the decision complained of violates in this respect the guaranties which are granted in favor of complainant by Articles I4, I6 and 27 of the Federal Constitution."

To the fourth of defendant's points the Court answers that the District Judge did consider the fact that the permits were merely provisional and subject to the Petroleum Law, but, although provisional, they were based on some of the rights enumerated by Article I4 of the Law. Having answered the first argument of the Attorney General in disposing of defendant's thi:d point, the Court then takes up the other contention that the Company had failed to prove its rights. The Court holds that an amparo suit is not the proper proceeding in which to establish property rights, ${ }^{25}$ and that insofar as the rights of the Company are concerned, there has been as yet no opportunity to prove them because "the examination of such rights must be made when the application for confirmation is presented to the Secretary of Industry, Commerce and Labor." In other words, until an opportunity is given to the company to prove its rights fully in appropriate proceedings, the prima facie case it made

\footnotetext{
${ }^{24}$ Sitpra p. 291.

${ }^{23}$ This is in accordance with Article ro7 of the Constitution of I9I7 and Article 2 of the Amparo Law of Igrg.
} 
out in the District Court is sufficient for the purposes of the Amparo Law.

The Court does not answer what seems like a very sound argument advanced by the Company, namely that simply requiring it to apply for a concession in exchange for its old titles is in itself a violation of the constitutional guaranties, particularly in view of the fact that the company is a foreign company and thus under the Constitution ${ }^{26}$ and the Petroleum Law ${ }^{27}$ it would seem that the Company cannot lawfully receive any concession. Justice Cisneros Canto, in his dissenting opinion, answers this with Article ${ }^{5} 59$ of the Regulations of the Petroleum Law. ${ }^{28}$ But can the express language of the Constitution and the Law be enlarged by mere Regulations?

The opinion then goes on to state that Article I4 of the Law requires a mere confirmation of pre-existing rights and hence cannot violate any precepts of the Constitution; that those preconstitutional rights could not be confirmed automatically by operations of law, because this would result in confusion, while a manifestation of such rights for the purpose of confirmation would enable the Government to issue the necessary police regulations. A parallel is sought to be found in the Law of Federal Waters, ${ }^{2 \theta}$ but the Court seems to overlook the fact that under the terms of that law, pre-existing rights were automatically confirmed "by virtue of the law" 30 and "respected and confirmed." 31

Having analyzed rather fully the Court's decision, let us now ascertain concretely what the decision holds. In short:

Article 27, supra note 12 .

${ }^{27}$ "Mexicans and civil and commercial companies organized under the laws of Mexico may obtain petroleum concessions subject to the precepts of this law. In addition to the foregoing limitation, aliens must previously comply with the requirements of Article 27 of the Political Constitution in force." Art. 4, Law of December 3I, I925.

2a "For the effects of Article 4 of the Law, should the holder of the rights recognized in Articles I2 and I4 of said Law and 157 of these Regulations be a foreign company or a Mexican company with foreign shareholders, said rights may be retained by such company . . . for so long as the contracts from which they emanate may be in force, or, as the case may be, for the time of duration of the company, according to its articles of association." Art. I59, Regulations, "Diario Oficial," April 8, 1926.

\footnotetext{
${ }^{2}$ Law of December I4, I9Io.

${ }^{80}$ Article 31, Law of December I4, I9I0.

"Article 32, Law of December 14, I9Io.
} 
(I) That the 50-year limitation on petroleum concessions established by Article I4 of the Petroleum Law is unconstitutional.

(2) That, consequently, the one-year period of grace from the promulgation of the Law contained in Article I 5 of the Law is void, and that the failure so to apply within the year cannot be considered as a waiver of certain pre-constitutional subsoil rights.

(3) That the rights which the Court protects relate to lands (a) acquired in fee prior to I9I7 and (b) on which regular works of petroleum exploitation have been carried on prior to that date. In other words, this is an affirmation of the doctrine of positive acts announced in the Texas Company amparo ${ }^{32}$ and reiterated by the Mexican Commissioners at the formal meeting of August 2, I923. ${ }^{33}$

(4) That the examination of pre-constitutional titles is to be made administratively by the Department of Industry, Commerce and Labor.

(5) That the nationalization of petroleum is generally confirmed and approved.

(6) That it is left in doubt how the "confirmation" of preconstitutional rights is to be made-apparently by means of "concessions." 34

( 7 ) That it is also left in doubt how the pre-constitutional rights of a foreign company may be "confirmed."

(8) That in order to obtain a confirmation of pre-constitutional rights, the holders thereof must, in addition, prove compliance "with the obligations contained in the respective titles."

The Press of the United States seems to have received the decision with universal praise and acclaim, ${ }^{35}$ but it is evident that

s2 See supra note I.

"See "Proceedings of the United States-Mexican Commission," p. 47. It will be noticed that the number of "positive acts" recognized in Article I4 of the Law and in this decision is greatly curtailed, particularly in the case of lands held in fee.

' So the Constitution (Article 27) and the Law (Articles 2, 4 and I4) would indicate.

"See "Our Oil Victory in Mexico," The Literary Digest, December 1o, 1927. 
while the decision undoubtedly points the way to a solution of the Petroleum Queston, it is far from fulfillng the legitimate. aspirations of the Oil Industry, or from meeting the just demands of our State Department. ${ }^{38}$ Before a complete and lasting settlement of the controversy may be hoped for certain legislative and even constitutional changes must be adopted, looking forward to the "true confirmation of pre-existing titles in their entirety." ${ }^{87}$ Until this is done, the development of the great natural resources in the subsoil of Mexico will continue to be handicapped and hindered, anci she further investment of foreign capital will be discouraged.

Let us hope that this decision may be the beginning of an era of better understanding between this country and Mexico, and the precursor of a stream of judicial decisions, followed by remedial legislation and an enlightened administrative policy which will inure to the lasting credit and continued prosperity of our great neighbor to the South.

"See "Correspondence Between the Governments of the United States and Mexico," as released for publication by the Department of State, November 24, 1926 (Reprint by Association of Producers of Petroleum in Mexico) and references on back cover page thereof.

" Note of the Secretary of State to the Mexican Minister for Foreign Affairs, dated July 31, 1926, Reprint, p. I2. 